\title{
Dal rilievo strumentale ai pannelli informativi tattili per un'utenza ampliata
}

Tommaso Empler

Alexandra Fusinetti

Abstract

I pannelli e modelli tridimensionali esplorabili 'apticamente' possono prevedere una modellazione 3D ed una successiva prototipazione additiva o sottrattiva, consentendo una duplice modalità di lettura: rinnovata o corretta interpretazione dell'effettiva forma dei luoghi nel passato; possibilità di far comprendere quegli stessi luoghi ad un pubblico più vasto ed ai disabili visivi.

II caso studio è quello delle Terme di Caracalla a Roma, dove una modalità di comunicazione e valorizzazione dei beni culturali diventa anche una palestra per effettuare rinnovate valutazioni sulla ricostruzione dell'area archeologica.

Parole chiave

disabile visivo, modellazione 3D, comunicazione tattile, stampa 3D.

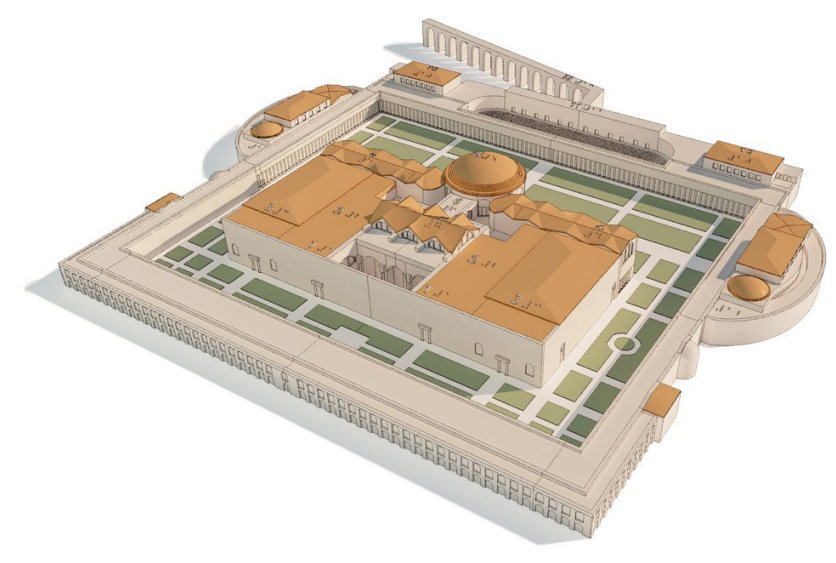




\section{Introduzione}

I pannelli ed i modelli tridimensionali, esplorabili 'apticamente' da parte dei disabili visivi, possono costituire un particolare output del rilievo integrato, dove l'acquisizione avviene mediante Terrestrian Laser Scanning (TLS) e fotogrammetria da drone.

Questo sviluppo è un ulteriore tassello della ricerca condotta dagli autori nella direzione della comunicazione a 'rilievo' dei beni culturali [Empler 2013; Empler 2020] e rivolta alla disabilità visiva.

Nelle precedenti fasi della ricerca l'attenzione è focalizzata sugli aspetti grafici, definendo il grado di astrazione rappresentativa sufficiente e necessaria alla comprensione dei pannelli tattili. Tra le buone pratiche individuate si segnala l'essenzialità del disegno, da generare attraverso segni e simboli in rilievo e tramite l'utilizzo di primitive geometriche (punti, linee, retini) e la necessità di utilizzare un supporto che abbia una superficie robusta ma gradevole al tatto. Si ricorda, infatti, che per un disabile visivo dalla nascita due rette parallele continuino a rimanere tali e a non convergere mai in un punto posto all'infinito. L'assonometria, isometrica o cavaliera, pur consentendo una rappresentazione precisa delle dimensioni degli oggetti, implica anch'essa una serie di deformazioni che non possono essere immediatamente colte dalla percezione aptica (Levi, Rolli 1994). Inoltre, la procedura individuata per la realizzazione dei pannelli visuo-tattili è in accordo con le Linee Guida del MIBACT del 2018.

Nell'attuale evoluzione della ricerca vengono esplorate le potenzialità connesse alla realizzazione di modelli 3D e di modelli fisici tramite procedure di prototipazione additiva e sottrattiva e come questi possano supportare anche il percorso delle ipotesi ricostruttive. I processi implicati sono molteplici e vanno dall'applicazione di metodologie legate alle ICT (Information and Communication Technologies) per la divulgazione dei beni culturali, a rinnovate interpretazioni delle strutture analizzate da parte di coloro che da molto tempo indagano in maniera scientifica uno specifico spazio, che, nel caso applicativo in questione, è costituito dalle Terme di Caracalla, con le ricerche ricostruttive della Dott.ssa Marina Piranomonte [I] [Piranomonte 2012] e dell'Arch. Maurizio Pinotti [2].

Registrazione dei dati, modellazione 3D e prototipazione additiva consentono una duplice modalità di lettura: rinnovata o corretta interpretazione dell'effettiva forma dei luoghi nel passato; possibilità di far comprendere quegli stessi luoghi ad un pubblico più vasto ed ai disabili visivi.

\section{Stato dell'arte}

La realizzazione di modelli fisici per far comprendere lo spazio e gli oggetti in esso presenti ha origine nel periodo rinascimentale, quando gli architetti sono soliti usare tale procedura per definire il lavoro, al punto da considerarlo il culmine di un modo di progettare l'archi-

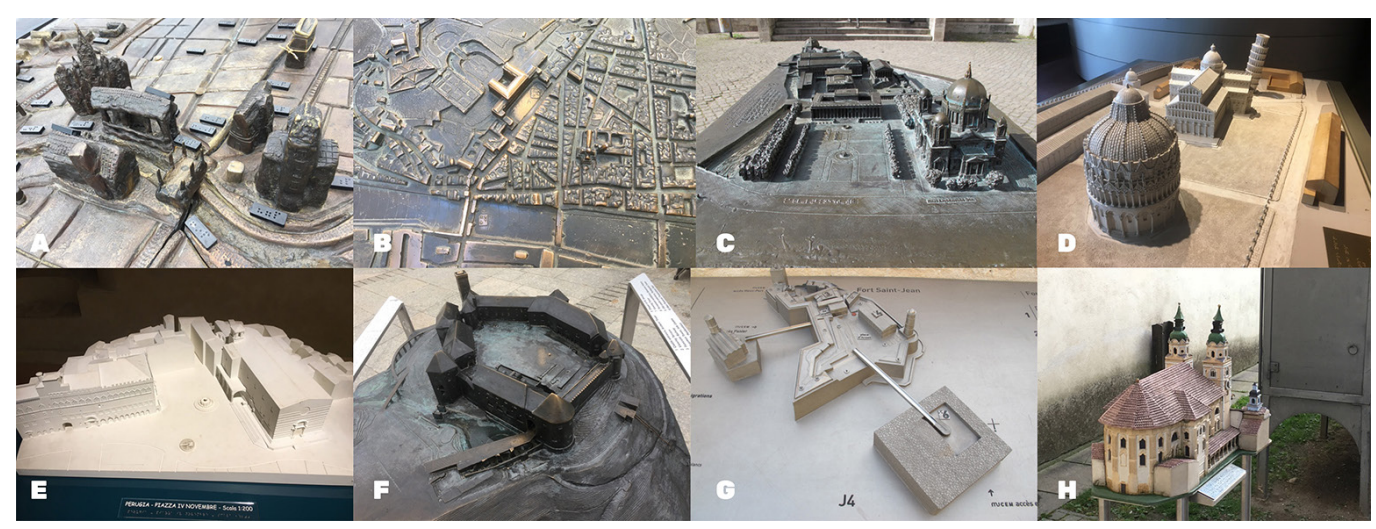


Fig. 2. In viola il rilievo fornito dalla Soprintendenza Speciale per i Beni Archeologici di Roma, a colori l'area mancante integrata con l'acquisizione di foto da drone.

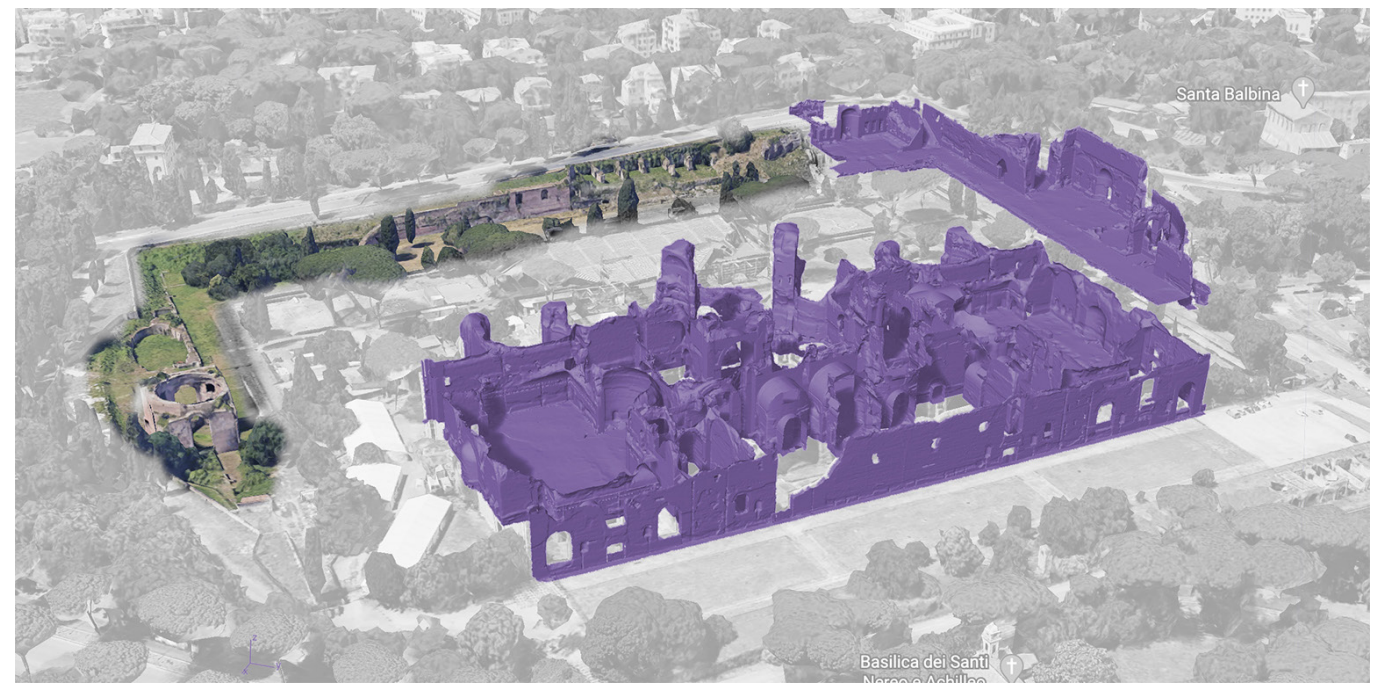

tettura. Insieme al Vasari che usa il modello in modo sistematico, troviamo tracce anche nell'esperienza di Andrea Palladio, rappresentativo di un altro modo di definire l'architettura, più accurata, con le procedure rappresentative più recenti a quel tempo, e separato dall'indispensabile modello preliminare.

Henry Millon [Millon 1994] sottolinea, invece, che per Leon Battista Alberti i modelli avevano un'altra importante funzione. A suo parere in architettura un'idea o 'disegno' poteva realizzarsi solo attraverso un modello. L'idea essendosi formata nella mente, era imperfetta, e poteva trovare la propria forma conseguente solo attraverso l'esame, la valutazione e le modifiche attuabili mediante i disegni, che poi venivano trasformati in modelli fisici.

Oggi i modelli fisici vengono utilizzati prevalentemente con modalità comunicative, con il fine di divulgare e far comprendere meglio gli spazi e/o agevolare i processi di wayfınding e di orientamento.

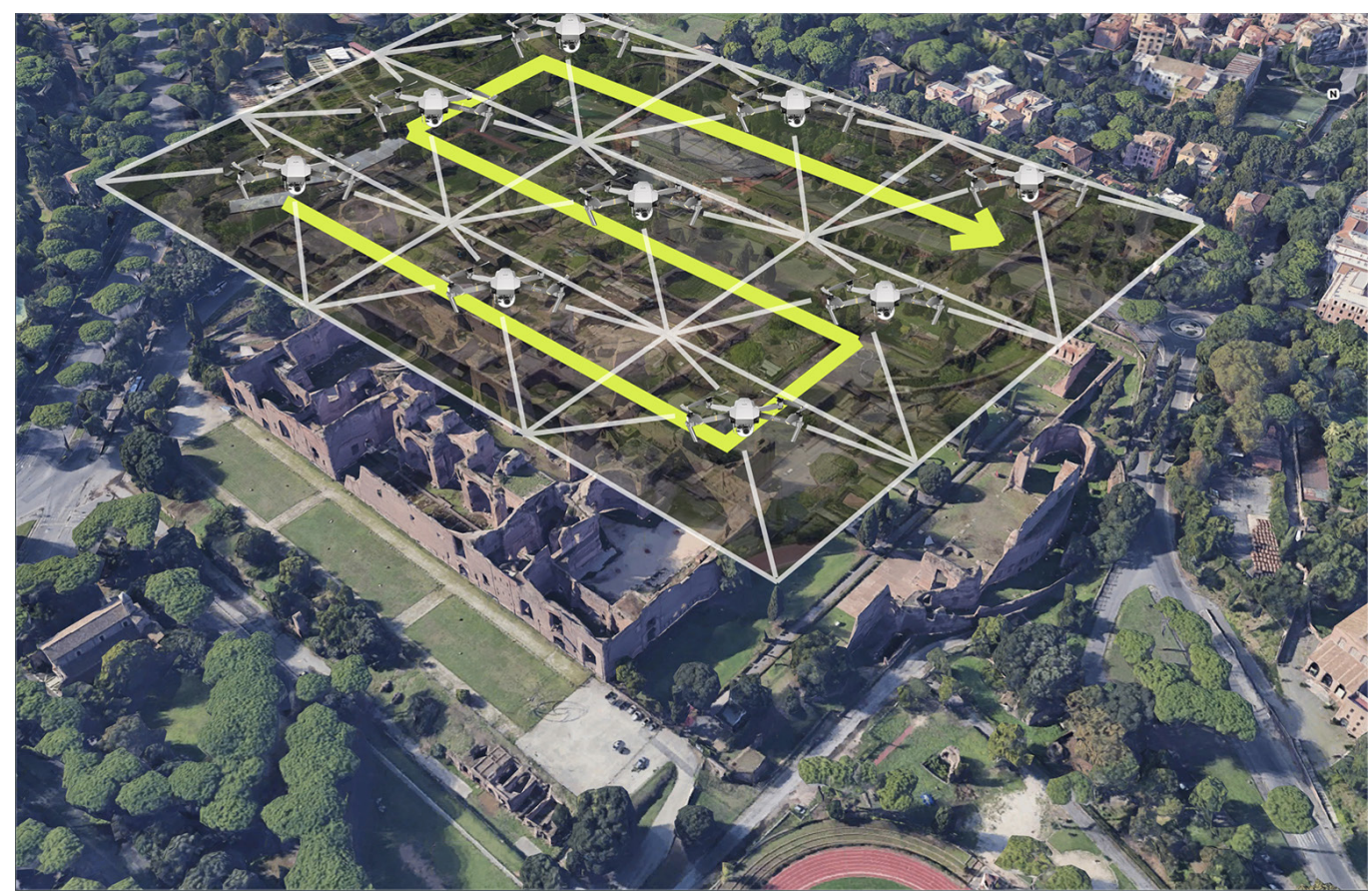


Fig. 4. Fasi di acquisizione e generazione della nuvola di punti, 'mesh' Tempio di Giove.

Fig. 5. Integrazione tra la 'mesh' proveniente dal TLS (in blu) e la

'mesh' acquisita con fotogrammetria (rosso).

Fig. 6. Modello tridimensionale dello stato attuale: in giallo le parti chiuse ai fini della sicurezza dell'esplorazione 'aptica' del fruitore.
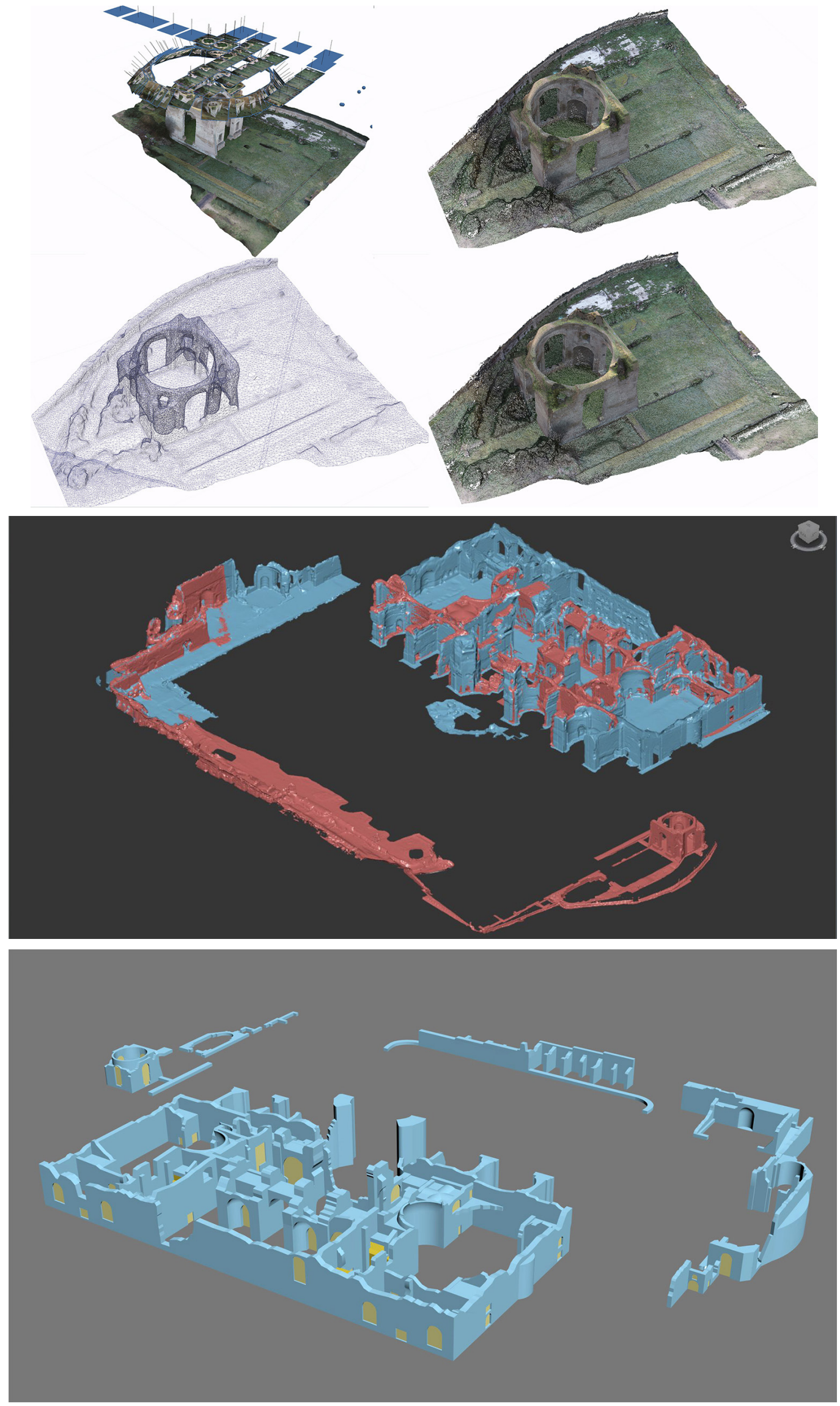
I materiali utilizzati e la scala di rappresentazione variano in funzione della collocazione (interna o esterna), della dimensione dello spazio da rappresentare (scala urbana o complesso di edifici), accuratezza dell'informazione trasmessa e percepita 'apticamente' (maggiori o minori dettagli in funzione della soglia di percezione tattile), qualità dell'esecuzione (artigianale o produzione con prototipazione additiva o sottrattiva) (fig. I).

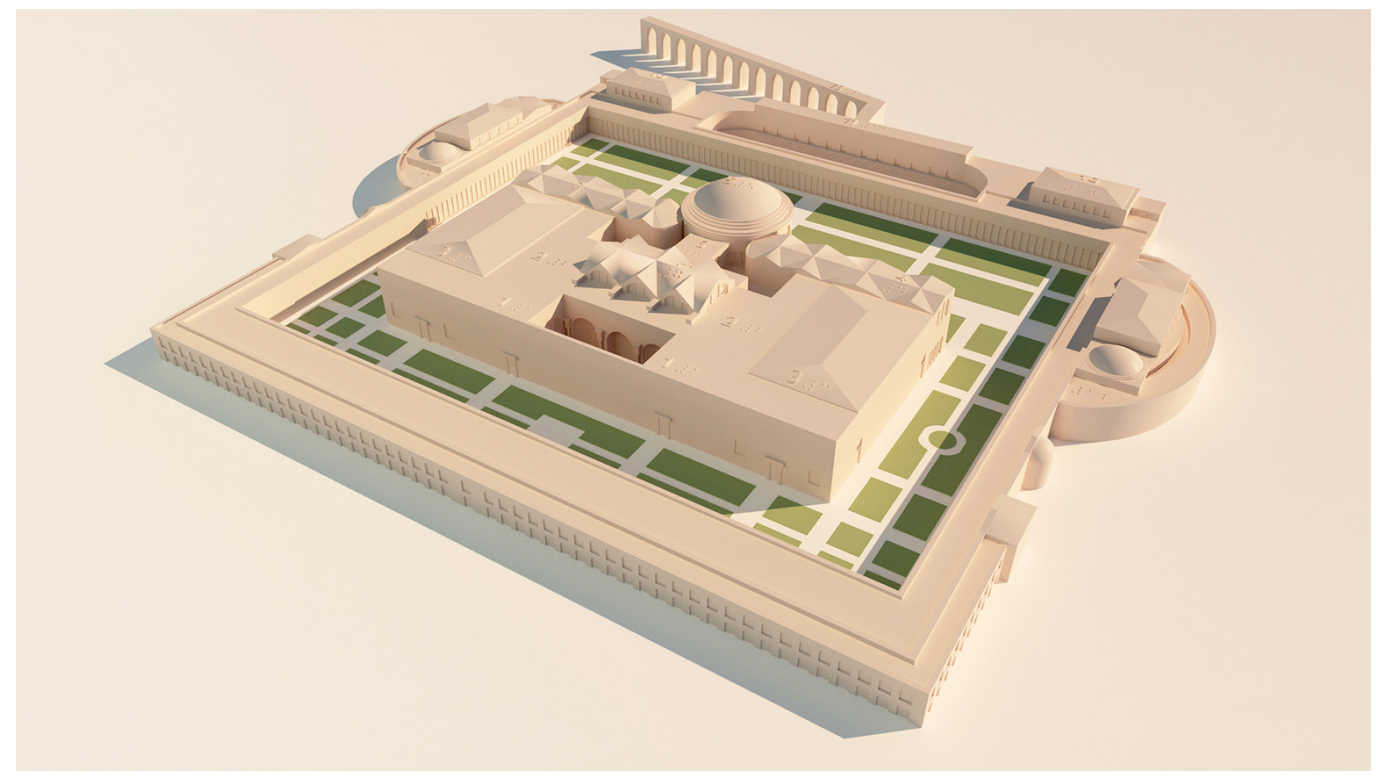

\section{Metodologia applicata}

La metodologia di registrazione dei dati, con un rilievo di tipo strumentale (TLS + Fotogrammetria), la successiva elaborazione e generazione di un modello 3D e l'uscita con strumenti di prototipazione additiva e sottrattiva, è ampiamente noto, documentato e utilizzato nel settore scientifico disciplinare del disegno [De Luca $20 \mathrm{l} \mathrm{I}$ ].

L'aspetto innovativo è costituito dalla flessibilità che tale procedura consente nel rivisitare le ipotesi di ricostruzione di siti storico-archeologici e di generare forme percepibili 'apticamente' da parte dei disabili visivi, dove rimane centrale il tema della soglia della percezione tattile in termini di esplorazione degli oggetti attraverso l'uso dei polpastrelli delle mani ed il raggio d'azione delle braccia.

Coniugare l'esigenza conoscitiva, le modalità rappresentative e la capacità di percepire l'informazione vede un apporto interdisciplinare tra il settore della rappresentazione, della tiflologia e dell'ergonomia, ai quali, in questo particolare periodo storico, bisogna anche aggiungere la prossemica e l'igiene.

La tiflologia [Wikipedia 202I] è la scienza che indaga le problematiche degli individui con disabilità visiva (ipovedenti e non vedenti) indicando le soluzioni per una piena integrazione sociale e culturale. L'apporto, in questo contesto, è sulla valutazione di quale tipo di informazione sia effettivamente percepibile 'apticamente' (esplorazione attiva di un oggetto con le dita di una mano) e/o percepibile con il residuo visivo da parte degli ipovedenti (per i quali sono percepibili gli oggetti e le figure con un contrasto di luminanza superiore al 40\%). A questi aspetti percettivi della tiflologia sono direttamente connesse alcune modalità rappresentative della scienza del disegno, ed in particolare: il rapporto figura-sfondo (dove viene gestito il rapporto tra ciò che deve essere comunicato e ciò che, invece, fa parte dello sfondo e riveste un ruolo secondario); la natura e qualità del segno (i tipi di segni e simboli realizzati in rilievo e percepibili 'apticamente'); la forma di rappresentazione (generalmente costituita da proiezioni ortogonali). 
Fig. 8. Rappresentazione grafica della ricostruzion da parte di InkLink.

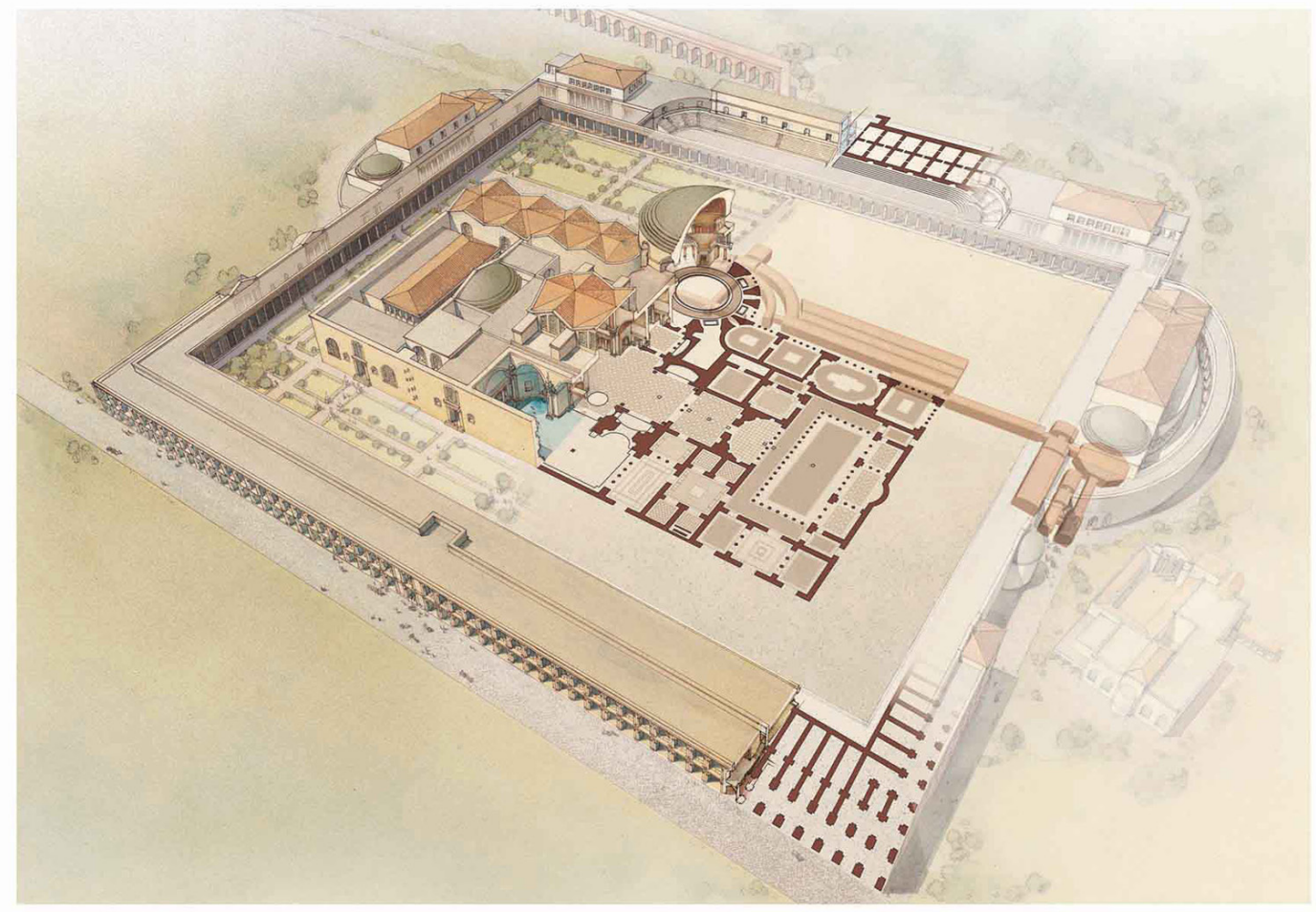

L'ergonomia incide sia sull'aspetto dimensionale complessivo dell'oggetto che deve essere esplorato, per posizione e postura del corpo (ovvero posizione rispetto ad un modello 3D o a un pannello informativo e valutazione di quale sia l'effettiva apertura delle braccia per l'esplorazione nella sua interezza), sia nella definizione degli elementi di dettaglio, dove la

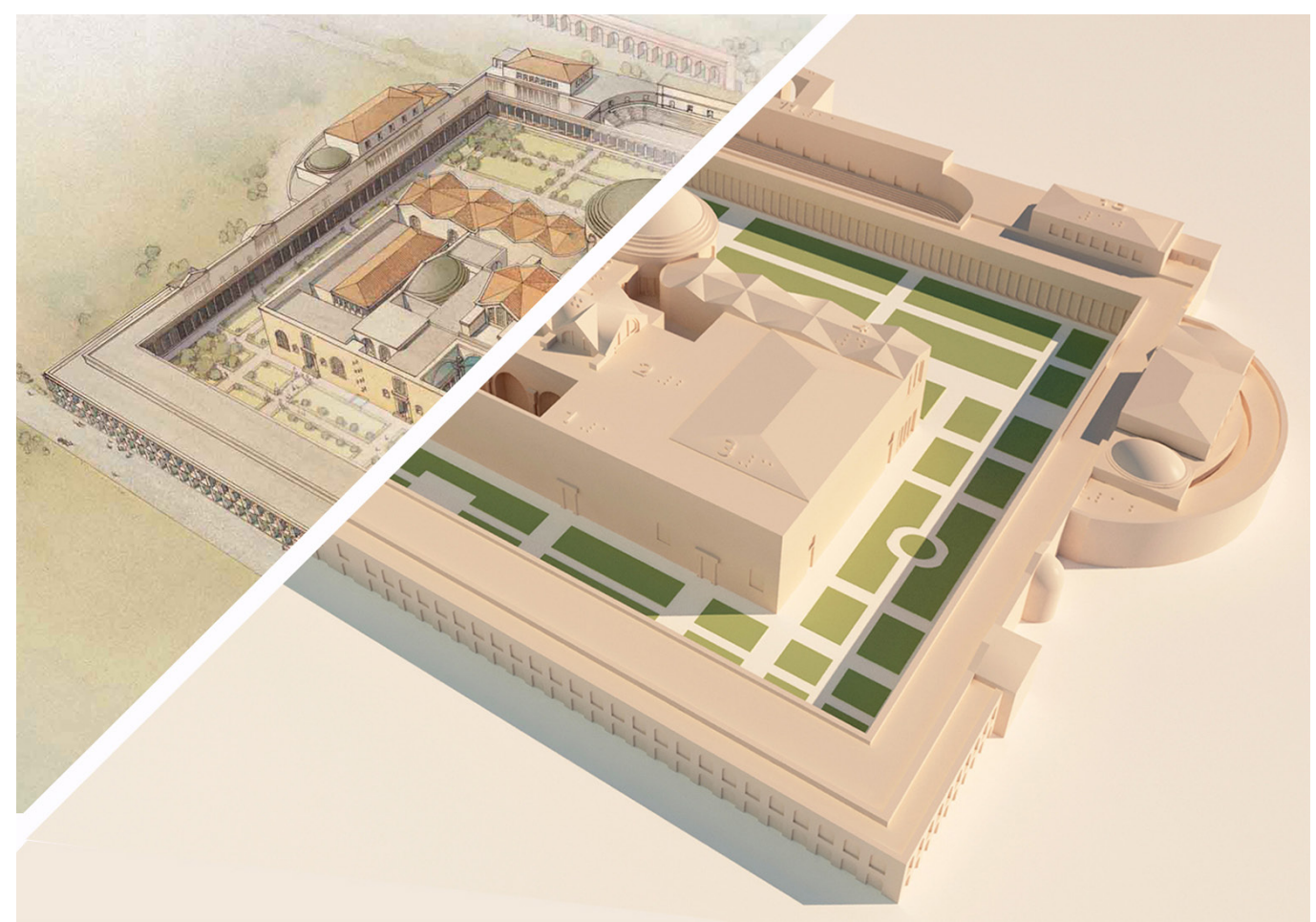

Fig. 9. Comparazione precedente (InkLink) e quella attuale.

L'aggiornamento ha

riguardato il sistema di coperture del nucleo centrale delle Terme. 


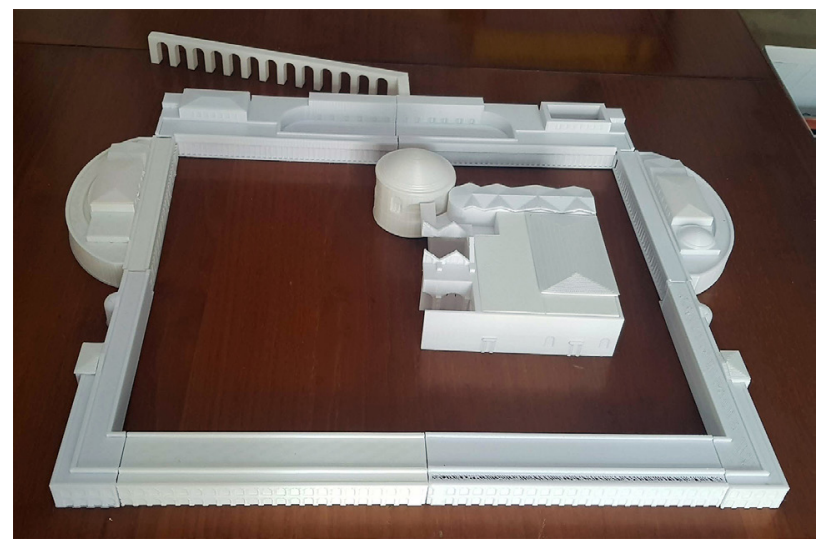

soglia dimensionale è costituita dall'effettiva capacità delle dita di esplorare e riconoscere i singoli elementi che fanno parte della composizione complessiva.

All'ergonomia viene anche associata la cognizione spaziale dei principali sistemi di riferimento, che possono essere 'egocentrici' o 'allocentrici' [Treccani 20 l0]. Nel primo caso gli oggetti sono raffigurati con riferimento alla posizione della testa e del corpo che deve esplorare lo spazio, nell'altro caso gli oggetti sono rappresentati in funzione delle loro proprietà spaziali e di configurazione.

La prossemica [Hall 1982] è vista come la scienza che definisce le distanze comportamentali degli individui, riconoscendo una distanza intima $(0-45 \mathrm{~cm}$ ), una distanza personale (45- I 20 $\mathrm{cm}$ ), sociale (da I a $2 \mathrm{~m}$ ) e pubblica (oltre i $2 \mathrm{~m}$ ). In un periodo storico in cui il 'distanziamento fisico o sociale' è una delle modalità individuate per evitare la propagazione del Covid- 19 , le distanze tra gli individui mutano i rapporti finora individuati dalla prossemica.

Infine, l'elemento legato all'igiene delle mani, che vengono considerate veicolo di trasmissione delle infezioni e quindi anche del Covid-19, individuando forme di igienizzazione che possano perdurare nel tempo.

Le potenzialità offerte da un modello tridimensionale derivante da rilievo integrato sono molteplici, non ultima la possibilità di utilizzo a fini comunicativi. Le Terme di Caracalla, uno dei più grandiosi esempi di terme imperiali a Roma, risalenti ai primi anni del III secolo ed ancora conservate per gran parte della loro struttura, hanno visto implementare tra i propri itinerari divulgativi l'esposizione di alcuni elementi caratteristici delle Terme, effettuata tramite l'utilizzo di pannelli tattili dedicati ai disabili visivi.

A questo tipo di pannelli, ottenuti mediante prototipazione sottrattiva e già oggetto delle fasi precedenti della ricerca, è stata affiancata una diversa tipologia di pannello tattile derivante da una lavorazione con prototipazione additiva.

In questa sede si focalizza l'attenzione sulle metodologie applicate per la creazione di un modello fisico destinato all'esplorazione 'aptica'. II processo è stato articolato in più fasi.

Fase I - Acquisizione dei dati

La documentazione di partenza è costituita da una nuvola di punti registrata con un rilievoTLS, fornito dalla Soprintendenza Speciale per i Beni Archeologici di Roma (fig. 2), completato con l'acquisizione mediante fotogrammetria da drone delle coperture e di tutta l'area posta a SE e SO, comprendente i resti del Tempio di Giove, lo stadio e una parte della biblioteca (fig. 3). Fase 2 - Elaborazione dei dati

La nuvola di punti proveniente dal rilievo TLS viene trasformata in una 'mesh' con l'ausilio di un software come CloudCompare, mentre le foto tratte dal drone sono elaborate con un software di fotomodellazione come Metashape, con un primo passaggio in nuvola di punti, uno successivo a 'mesh' ed infine in 'mesh texturizzate'. I due modelli sono sovrapposti mediante l'uso di un software di gestione 'mesh' come Meshlab (figg. 4, 5).

Successivamente all'operazione di controllo delle forme e pulizia del modello, si è proceduto alla generazione di due sotto-modelli: il modello dello stato attuale delle rovine e un modello ricostruttivo dell'aspetto delle Terme nel periodo del loro massimo splendore. 


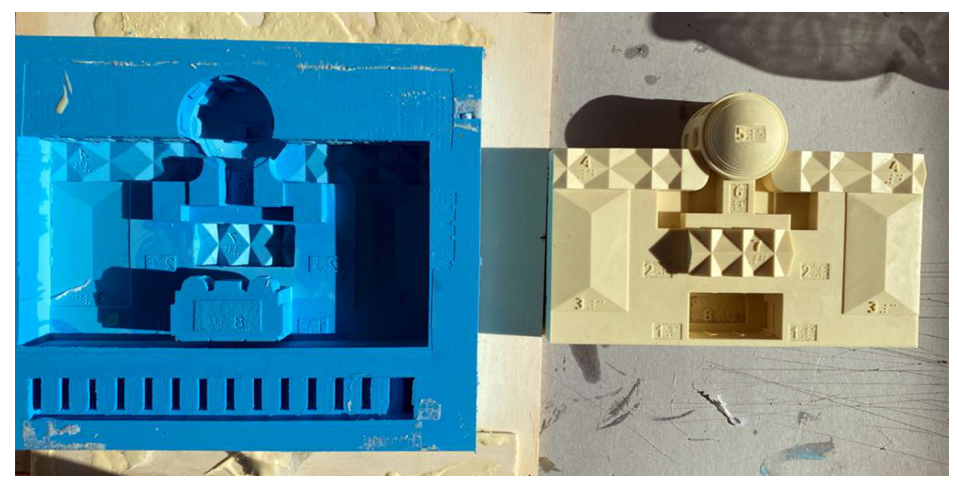

La creazione del modello tridimensionale delle rovine è più agevole, perché comporta una 'semplificazione' della 'mesh', ottenuta dal rilievo integrato, con le riduzioni necessarie ad ottenere una corretta comprensione dell'area ai disabili visivi. II modello 3D viene integrato e trasformato andando a chiudere, riempire o ridurre quelle parti che possono costituire un pericolo durante l'esplorazione 'aptica' (fig. 6).

La ricostruzione dello stato originario prevede un lavoro più accurato. Le precedenti ipotesi ricostruttive, comprendenti alcune visualizzazioni elaborate dallo studio InkLink, su indicazione della Dott.ssa Piranomonte, sono state confrontate con i dati ottenuti dal rilievo integrato e con le ulteriori scoperte e valutazioni ottenute durante i lavori di restauro della parte superiore delle Terme. Questo produce nuovi convincimenti sull'organizzazione degli spazi, soprattutto delle grandi palestre, per le quali è possibile ipotizzare nuove coperture, che superano tutte le ipotesi formulate in precedenza. (figg. 7-9)

Fase 3 - Utilizzo dei dati

Validati i due modelli tridimensionali da parte dei referenti della Soprintendenza Speciale per i Beni Archeologici di Roma, si è passati alla realizzazione del modello fisico, anch'esso generato seguendo diverse fasi e procedure.

II modello è pensato per essere fruito all'esterno, collocato nel piazzale di accesso. Tra i requisiti richiesti vi è la resistenza alle intemperie, ed essere realizzato con un materiale che ne permetta un'esplorazione aptica durante tutto l'arco dell'anno. Ė scartata l'idea di produrlo utilizzando un materiale metallico, proprio per le elevate temperature che raggiungerebbe nel periodo estivo, facendo ricadere la scelta su un materiale resinoso, piacevole al tatto e che risolve il problema del surriscaldamento.

Per ottenere il modello finale in resina è prima necessario produrre una matrice in negativo dentro cui colare il materiale, matrice a sua volta generata a partire da un modello fisico stampato in 3D. La fase precedente a quella di stampa vede la suddivisione dei modelli in parti più piccole, in modo che rientrino nei limiti del piatto di stampa; per velocizzare i tempi i modelli sono stampati utilizzando tre diverse stampanti, tutte con tecnologia FDM (Fused Deposition Modeling) e mediante estrusione di PLA (acido polilattato, realizzato con risorse rinnovabili annualmente come l'amido di mais o la canna da zucchero) (fig. I0).

Completata la stampa, prima della realizzazione della matrice in silicone (fig. I I), è necessario un ulteriore passaggio di rifinitura dell'oggetto per eliminare alcuni dei segni derivanti dal processo di prototipazione additiva.

Il modello fisico è infine posizionato e fissato mediante viti su una base in policarbonato, realizzata secondo la metodologia già acquisita e testata nelle fasi precedenti della ricerca, con prototipazione sottrattiva, a sua volta collocata su un leggio orizzontale (fig. I2).

\section{Conclusioni}

La procedura applicata consente una sua replicabilità in altre aree di interesse culturale, consentendo allo stesso tempo sia una evoluzione delle ipotesi di ricostruzione dei siti dal punto di vista scientifico, sia una loro maggiore fruibilità ad un pubblico di visitatori più vasto, rendendo l'area più inclusiva. 
Fig. 12. I modelli stampati e collocati sui leggii

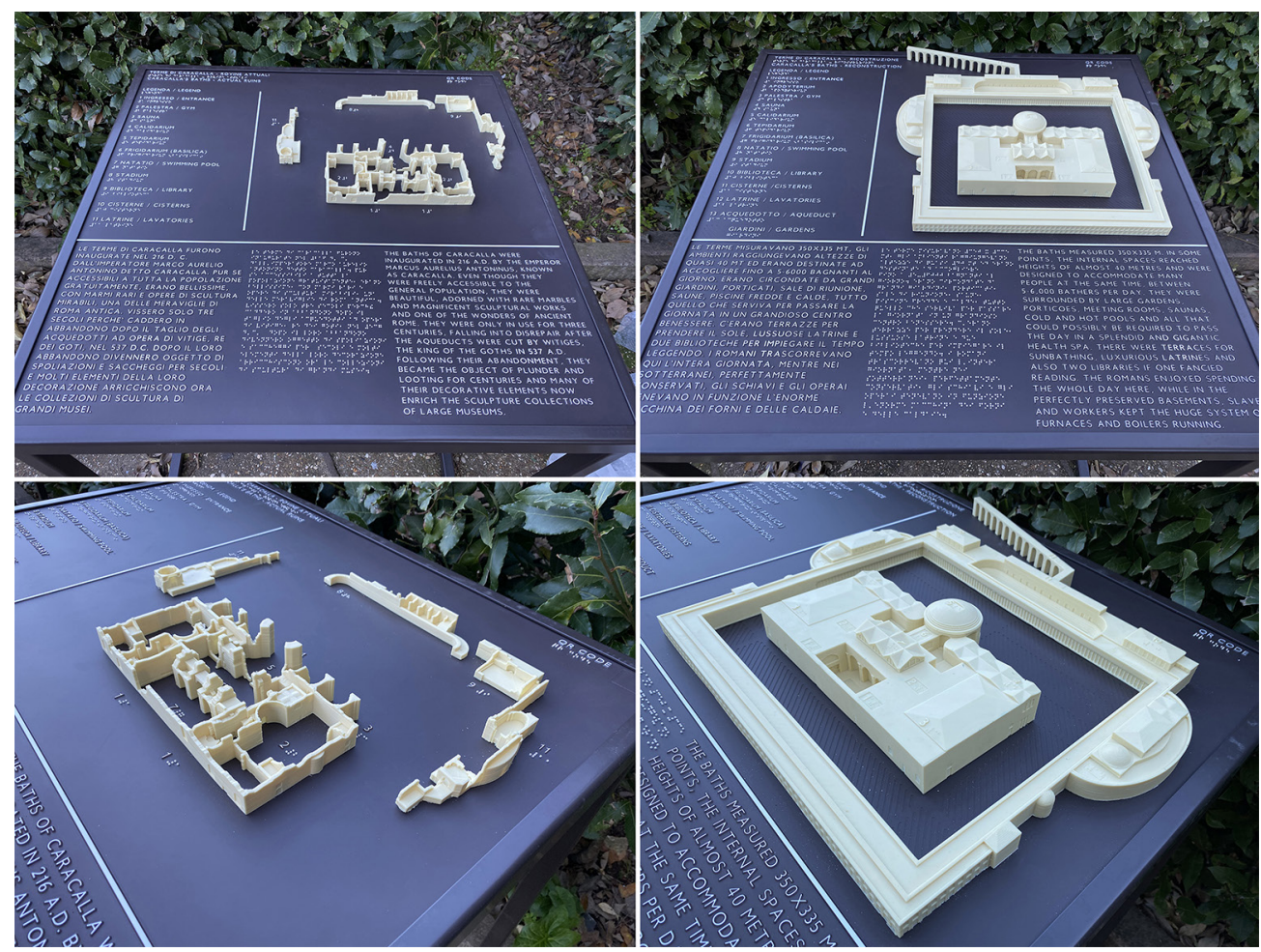

\section{Note}

[I] Direttore archeologo coordinatore Soprintendenza Speciale per i Beni Archeologici di Roma, Direttore delle Terme di Caracalla.

[2] Soprintendenza Speciale per i Beni Archeologici di Roma, Supervisore Tecnico delle Terme di Caracalla.

\section{Riferimenti bibliografici}

De Luca L. (20 I I). La fotomodellazione architettonica. Rilievo, modellazione, rappresentazione di edifici a partire da fotografie. Palermo: Dario Flaccovio Editore.

Empler T. (20 I 3). Universal Design: ruolo del Disegno e Rilievo. In Disegnare. Idee Immagini, n. 46, pp. 52-63.

Empler T., Fusinetti A. (2020). Rappresentazioni a rilievo nei percorsi museali. In diségno, n. 6, pp. I69- I78.

Hall E.T. (1982). La dimensione nascosta. Milano: Bompiani.

Lemma: "Cognizione spaziale". In Treccani Dizionario di Medicina. <https://www.treccani.it/enciclopedia/cognizione-spaziale_\%28Dizionario-di-Medicina\%29/> (consultato il 24 gennaio 202I).

Lemma: “Tiflologia”. In Wikipedia. <https://it.wikipedia.org/wiki/Tiflologia> (consultato il 24 gennaio 202I).

Millon H.S. ( 1994). I modelli architettonici nel Rinascimento. In Millon H.S., Magnago, Lampugnani V. (a cura di), Rinascimento da Brunelleschi a Michelangelo. La rappresentazione dell'Architettura, pp. 19-74. Milano: Bompiani.

Piranomonte M. (20I2). Le terme di Caracalla/The Baths of Caracalla. Milano: Mondadori-Electa.

Autori

Tommaso Empler, Sapienza Università di Roma, tommaso.empler@uniromal.it

Alexandra Fusinetti, Sapienza Università di Roma, alexandra.fusinetti@uniromal.it

Per citare questo capitolo: EmplerTommaso, Fusinetti Alexandra (2021). Dal rilievo strumentale ai pannelli informativi tattili per un'utenza ampliata/From Instrumental Surveys to Tactile Information Panels for Visually Impaired. In Arena A. Arena M. Mediati D. Raffa P. (a cura di). Connettere Un disegno per annodare e tessere Lingugogi Distanze Tecnologie. Atti del $42^{\circ}$ Convegno Internazionale dei Docenti delle Discipline della Roppresentazione/Connecting. Drawing for weaving relationship. Languages Distances Technologies. Proceedings of the 42th International Conference of Representation Disciplines Teachers. Milano: FrancoAngeli, pp. 2265-2282 


\section{From Instrumental Surveys to Tactile Information Panels for Visually Impaired}

Tommaso Empler

Alexandra Fusinetti

Abstract

Three-dimensional panels and models, that can be explored 'aptically', can include 3D modeling and additive or subtractive prototyping, allowing a double reading method: renewed or correct interpretation of the actual shape of historical places; possibility of making those places better understand to a wider audience and to visually impaired people. Case study are the Baths of Caracalla in Rome, where a method of communication and enhancement of cultural heritage also becomes a training ground for carrying out renewed assessments on the reconstruction of the archaeological area.

Keywords

visually impaired, 3D modeling, tactile communication, 3D printing.

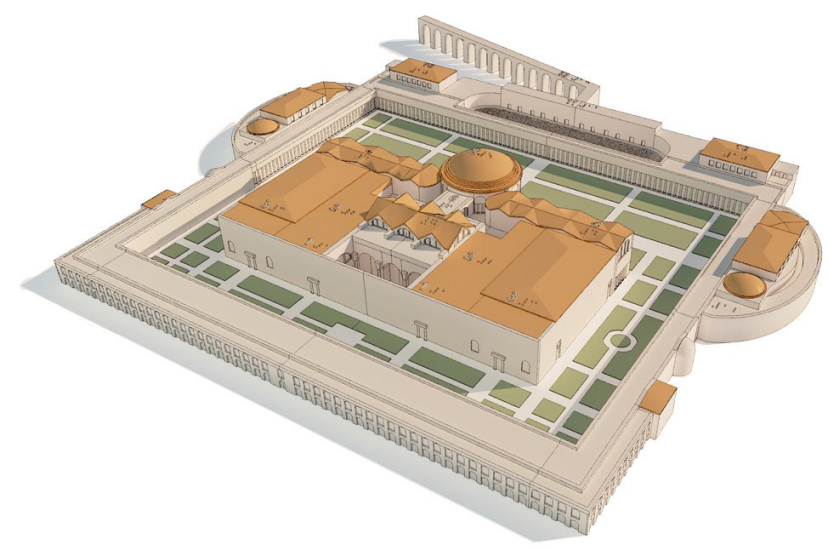




\section{Introduction}

Panels and three-dimensional models, which can be 'aptically' explored by the visually impaired, can constitute a particular output of an integrated survey, where acquisition takes place using Terrestrian Laser Scanning (TLS) and drone photogrammetry.

This development is a further step of the research developed by the authors towards a cultural heritage's "communication in relief" [Empler, 2013 ; Empler 2020], for the benefit of visual impairment.

In previous phases of the research, attention was focused on graphic aspects, defining the degree of representative abstraction that is sufficient and necessary for understanding tactile panels. Among the identified good practices, is to be noted the essentiality of representation, generated through signs and symbols in relief and through the use of geometric primitives (points, lines, hatches) and the need to use a support that has a robust but pleasant surface to the touch. It should be remembered, in fact, that for a visually impaired person from birth two parallel lines continue to remain so and never converge in a point placed at infinity. Axonometry, isometric or cavalier, while allowing a precise representation of the dimensions of objects, also implies a series of deformations that cannot be immediately grasped by haptic perception [Levi 1994]. Furthermore, the procedure identified for the realization of the visual-tactile panels is in accordance with the 2018 MiBACT Guidelines. In the current evolution of research, the potential associated with creation of 3D models and physical models is explored through additive and subtractive prototyping procedures and how these can also support the path of reconstructive hypotheses.

The processes involved range from the application of methodologies related to ICT (Information and Communication Technologies) for the dissemination of cultural heritage, to renewed interpretations of the structures analyzed by those who have been scientifically investigating a specific space for a long time, which, in this case, consists of the Baths of Caracalla, with the reconstructive research of Dr. Marina Piranomonte [Piranomonte 20I2] and Arch. Maurizio Pinotti.

Data recording, 3D modeling and additive prototyping allow a double reading mode: renewed or corrected interpretation of the actual shape of places in the past; possibility of making those same places understand to a wider audience and to visually impaired people.

\section{State of the art}

Creating physical models to help understand space and objects in it, originates in the Renaissance period, when architects used to practice this procedure to define a work, to the point of considering it the culmination of a way of designing architecture. Together with Vasari who uses the model in a systematic way, we also find traces in the experience of Andrea Palladio, representative of another way of defining architecture, more accurate, with the

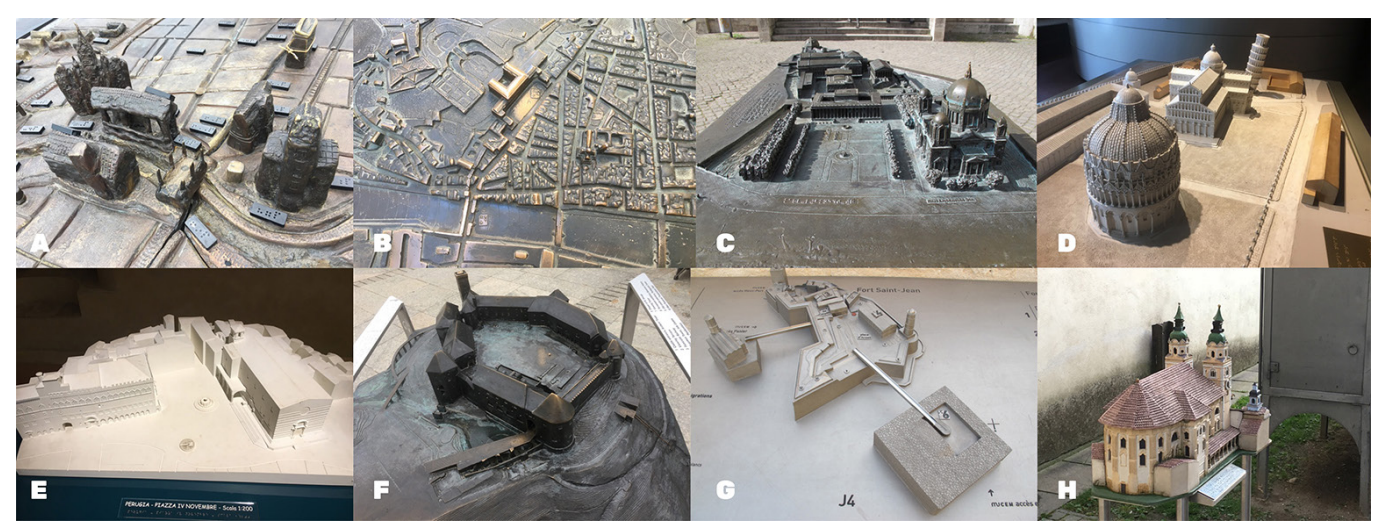


Fig. 2. In purple survey provided by the Specia Superintendency for

Archaeological Heritage of Rome, in color the missing area integrated with the acquisition of drone photos.

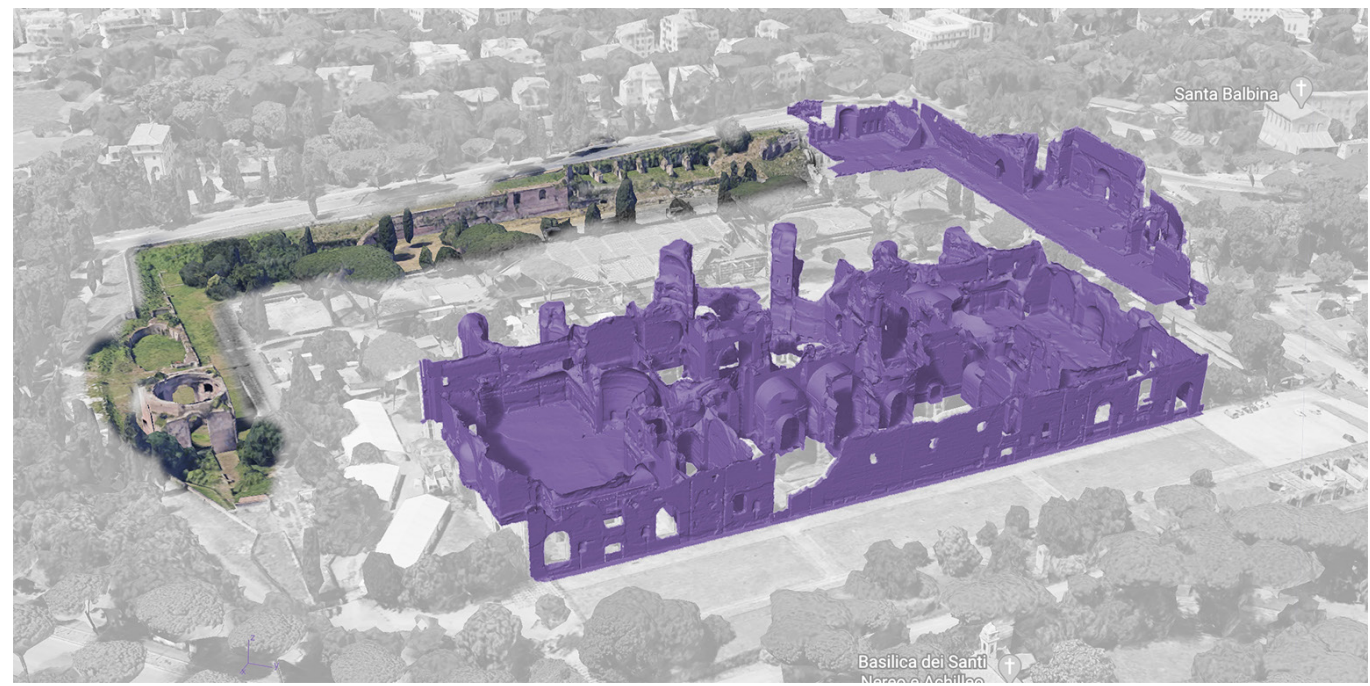

most recent representative procedures at that time, and separated from the indispensable preliminary model.

Henry Millon [Millon 1994] emphasizes, however, that to Leon Battista Alberti models had another important function. In his opinion, in architecture, an idea or 'design' could only be realized through a model. Having formed it in the mind, the idea was imperfect, and could only find its consequent form through examination, evaluation and modifications that could be implemented through drawings, which were then transformed into physical models.

Today physical models are mainly used with communication methods, with the aim of disseminating and making spaces better understandable and / or facilitating wayfinding and orientation processes.

Materials used and the scale of representation vary according to the location (internal or external), the size of the space to be represented (urban scale or complex of buildings),

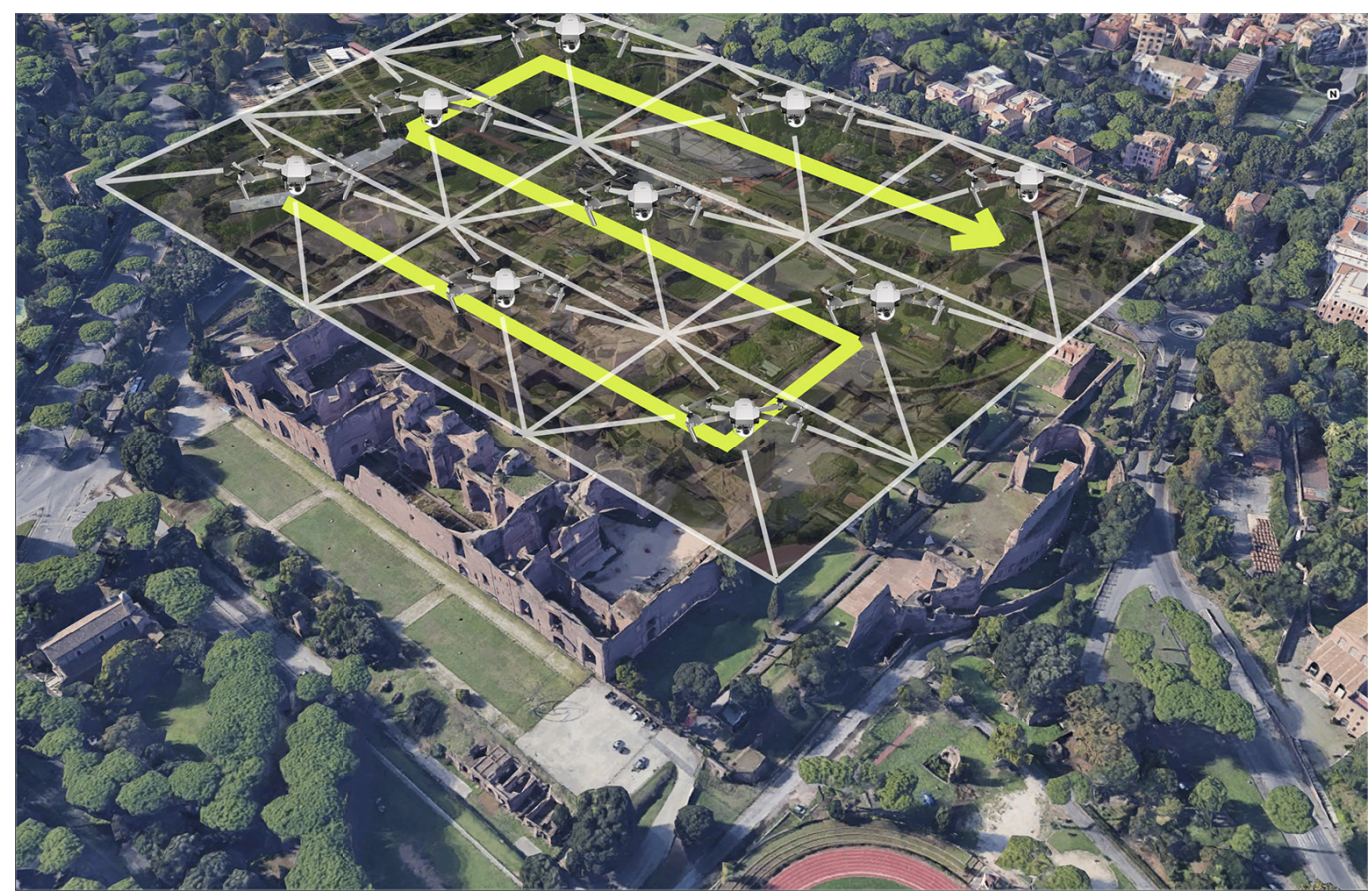


Fig. 4. Phases of acquisition and

generation of point cloud Temple of Jupiter are

Fig. 5. Integration

between 'mesh' coming

(in blue) and

the 'mesh' acquired with photogrammetry (red)
Fig. 6. Three-dimensional model of the current state: in yellow closed parts for the sake of the user's haptic exploration safety.
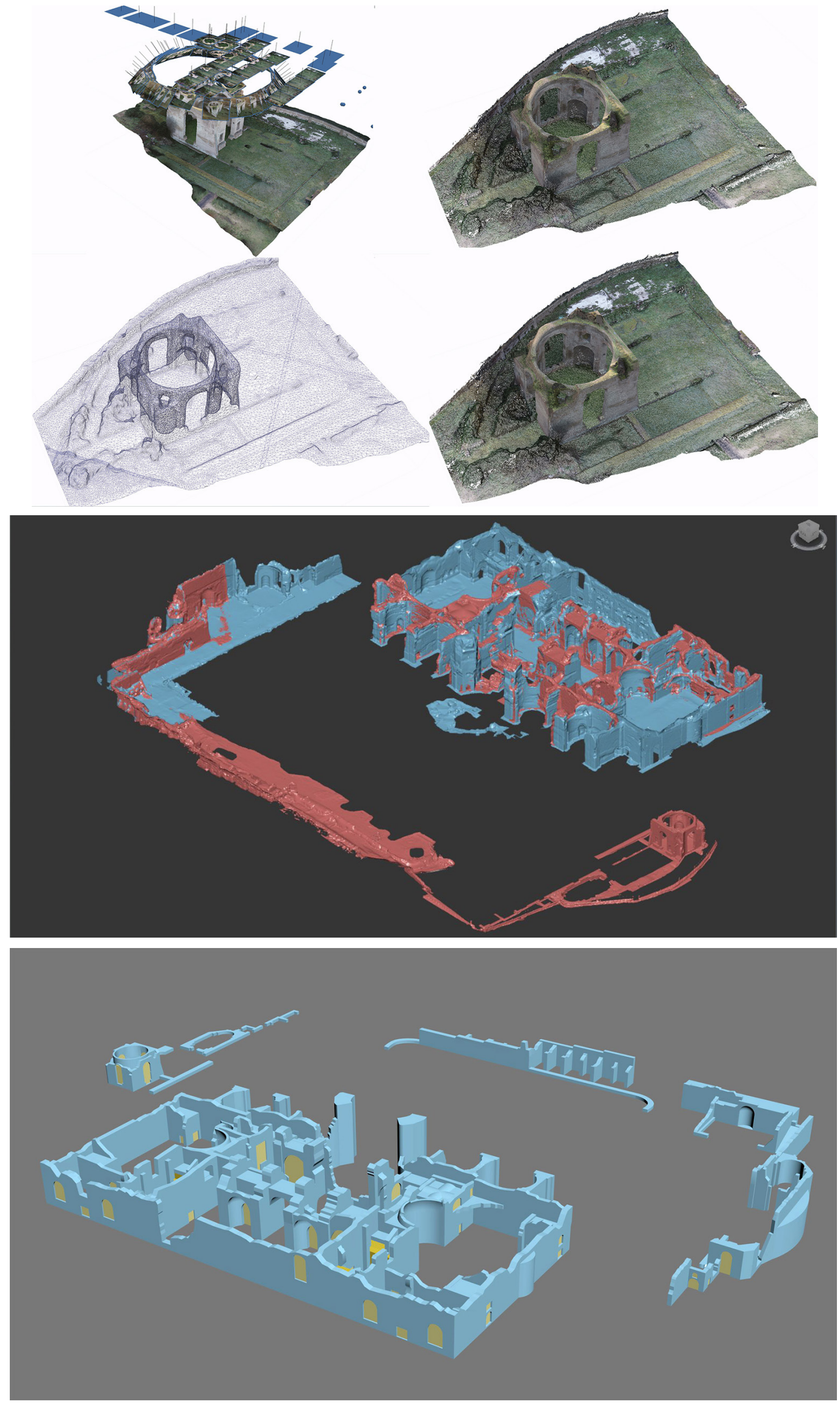
accuracy of the information transmitted and perceived haptically (greater or lesser details depending on the tactile perception threshold), quality of execution (craftsmanship or production with additive or subtractive prototyping) (fig. I).

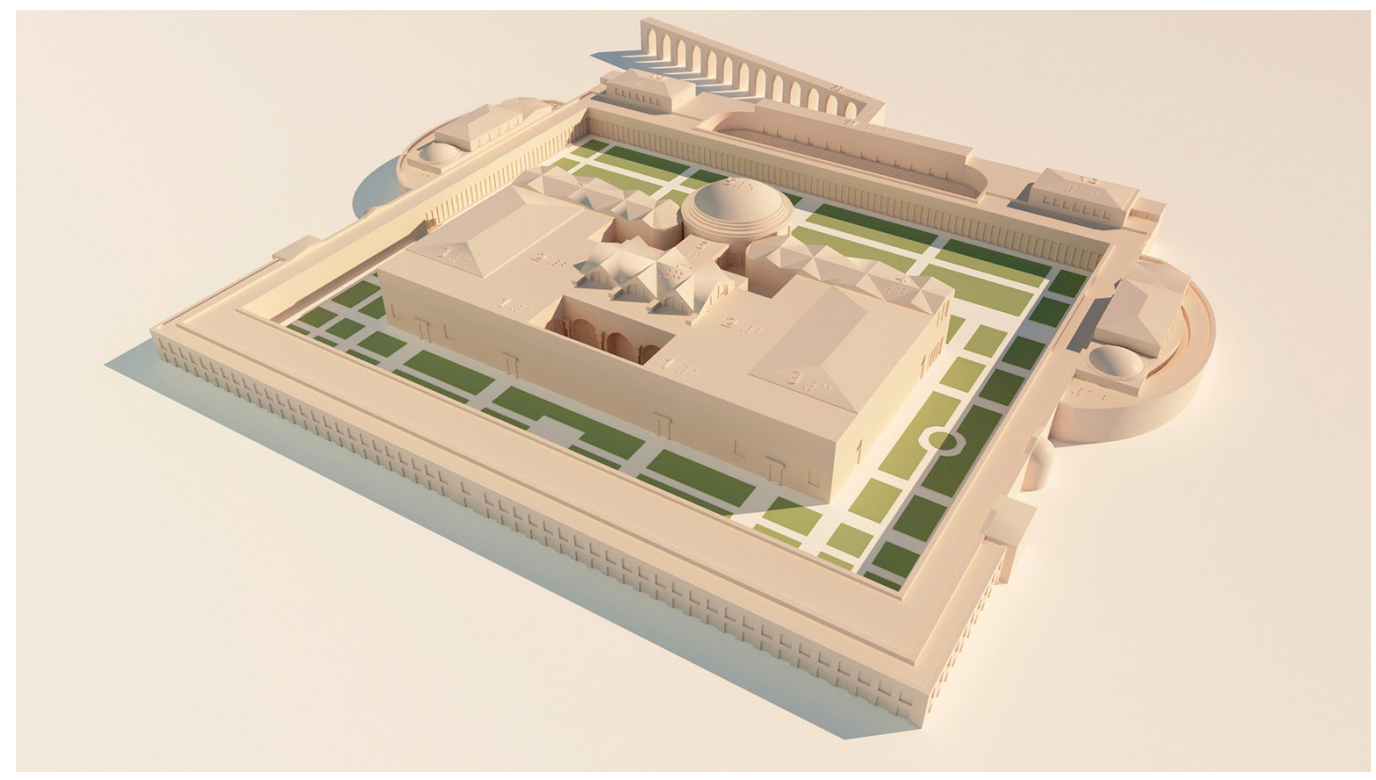

\section{Methodology}

Data recording methodology, with an instrumental survey (TLS + Photogrammetry), subsequent processing and generation of a 3D model and the output with additive and subtractive prototyping tools, is widely known, documented and used in the scientific sector of representation [De Luca $20 \mathrm{II}$ ].

The innovative aspect of the research is constituted by the flexibility that this procedure allows in revisiting the hypotheses of reconstruction of historical-archaeological sites and to generate forms perceptible haptically by the visually impaired, where the theme of threshold of tactile perception remains central in terms of exploration of objects through use of fingertips and range of action of arms.

Combining a need for knowledge, representative modalities and the ability to perceive information sees an interdisciplinary contribution between sectors of representation, typhlology and ergonomics, to which, in this particular historical period, it is also necessary to add proxemics and hygiene.

Typhlology [Wikipedia 202I] is a science that investigates problems of people with visual impairments (visually impaired and blind), indicating solutions for full social and cultural integration. Contribution, in this context, is on the evaluation of what type of information is actually haptically perceptible (active exploration of an object with the fingers of one hand) and / or perceptible with visual residue by visually impaired (for whom they are objects and figures with a luminance contrast greater than $40 \%$ can be perceived).

To these perceptive aspects of typhlology are directly connected some representative modalities of the science of representation, and in particular: figure-background relationship (where the relationship between what must be communicated and what, instead, forms part of the background and covers has a secondary role); nature and quality of the sign (types of signs and symbols made in relief and perceptible haptically); form of representation (generally consisting of orthogonal projections).

Ergonomics affects both the overall dimensional aspect of the object to be explored, by position and posture of the body (i.e. relative position to a 3D model or an information 
Fig. 8. Graphica

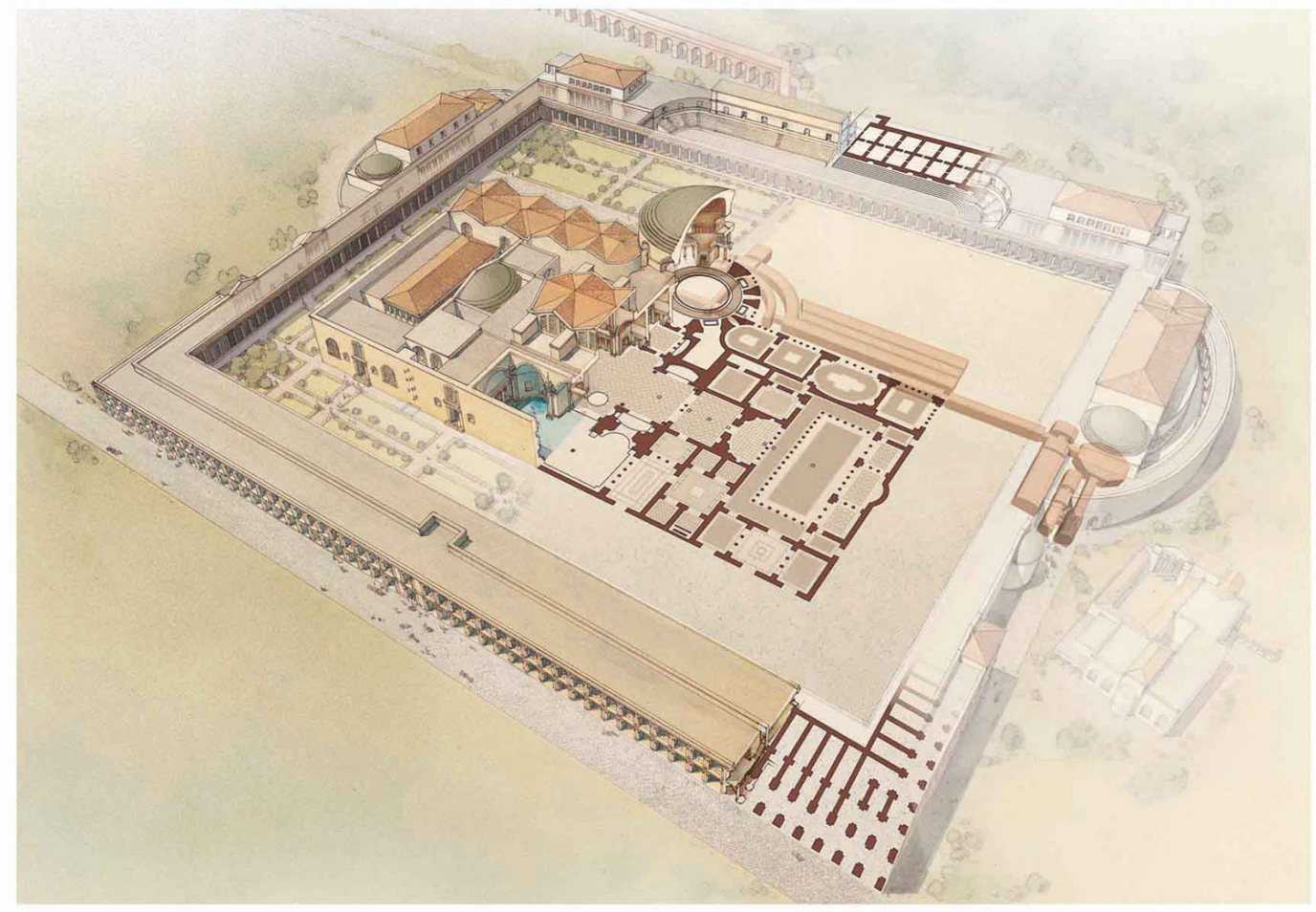

panel and evaluation of what is the effective opening of the arms for the exploration in its entirety), and in definition of the detailed elements, where the dimensional threshold is constituted by the effective ability of the fingers to explore and recognize each element that is part of the overall composition.

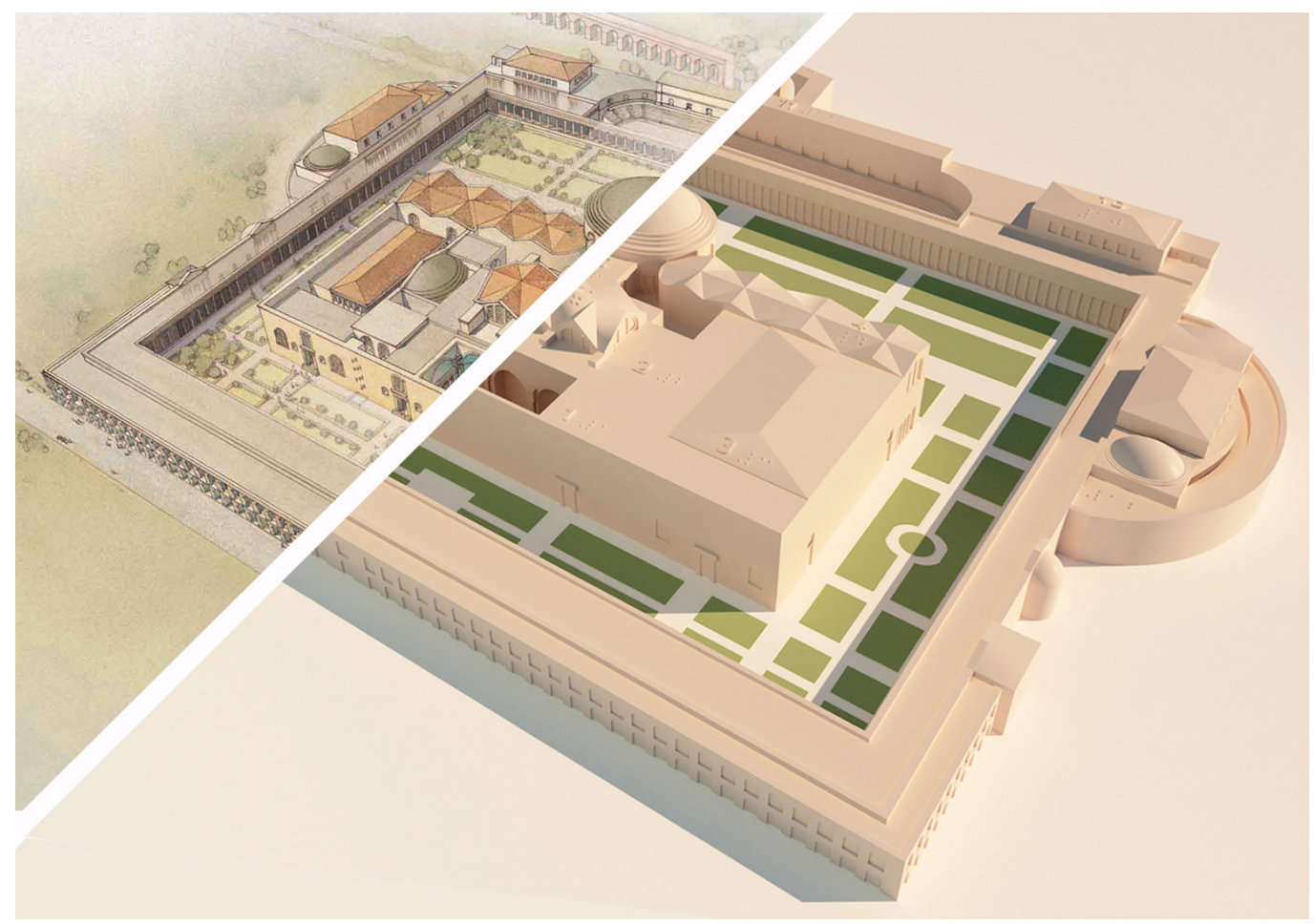


Fig. 10. Test prototype of reconstructive model. Printed with Creality Ender 5.

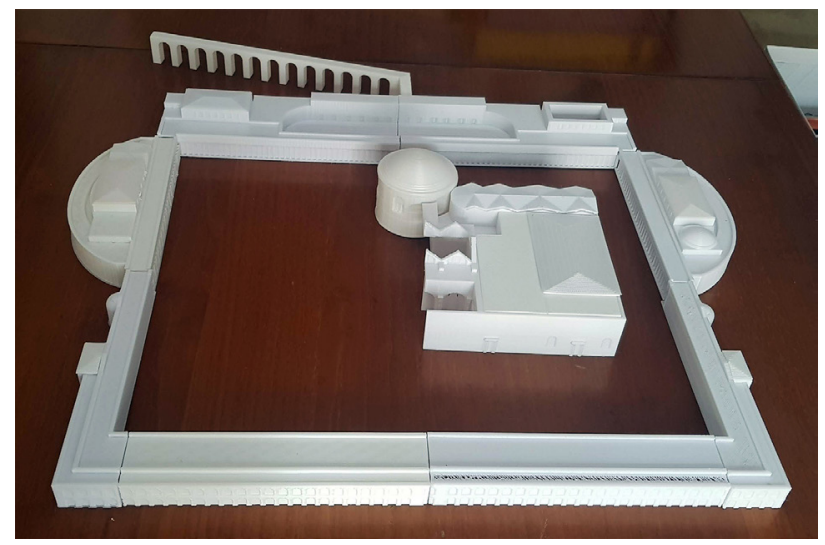

Ergonomics is also associated with spatial cognition of the main reference systems, which can be 'egocentric' or 'allocentric' [Treccani 20I0]. In the first case, objects are depicted with reference to the position of the head and body that must explore space, in the other case, objects are represented according to their spatial and configuration properties.

Proxemics [Hall 1982] is seen as the science that defines the behavioral distances of individuals, recognizing an intimate distance $(0-45 \mathrm{~cm})$, a personal distance $(45-120 \mathrm{~cm})$, a social distance (from I to $2 \mathrm{~m}$ ) and public (over $2 \mathrm{~m}$ ). In a historical period in which "physical or social distancing' is one of the ways identified to avoid the spread of Covid-19, distances between individuals change the relationships identified so far by proxemics.

Finally, element linked to hand hygiene, which are considered a vehicle for the transmission of infections and therefore also of Covid-19, identifying forms of sanitation that can last over time.

Potential offered by a three-dimensional model deriving from an integrated survey are many, even the chance to use it for communication purposes.

Baths of Caracalla, one of the most grandiose examples of imperial baths in Rome, dating back to the early third century and still preserved for most of their structure, have seen the implementation, among their popular itineraries, of some characteristic elements of the Baths, carried out through the use of tactile panels dedicated to visually impaired people.

This type of panels, obtained by subtractive prototyping and already subject of previous phases of the research, was accompanied by a different type of tactile panel deriving from processing with additive prototyping.

Here, attention is focused on methodologies applied for the creation of a physical model intended for haptic exploration.

The process was divided into several phases.

Phase I - Data acquisition

Starting documentation consists of a point cloud recorded with a TLS survey, provided by the Special Superintendence for Archaeological Heritage of Rome (fig. 2), completed with the acquisition by drone photogrammetry of the roofs and of the whole area located to the SE and SW, including the remains of the Temple of Jupiter, the stadium and part of the library (fig. 3).

Phase 2 - Data processing

Point cloud coming from TLS survey is transformed into a mesh with the help of a software such as CloudCompare, while the photos taken from drone are processed with a photo-modeling software such as Metashape, with a first step in a point cloud, one subsequent to mesh and finally textured. Two models are superimposed through the use of a mesh management software such as Meshlab (fig. 4, 5).

After checking the shapes and cleaning the model, two sub-models were generated: model of the current state of the ruins and a reconstructive model of the appearance of the Baths in the period of their maximum splendor. 
Fig. I I. Silicone matrix (in blue) and resulting resin model.

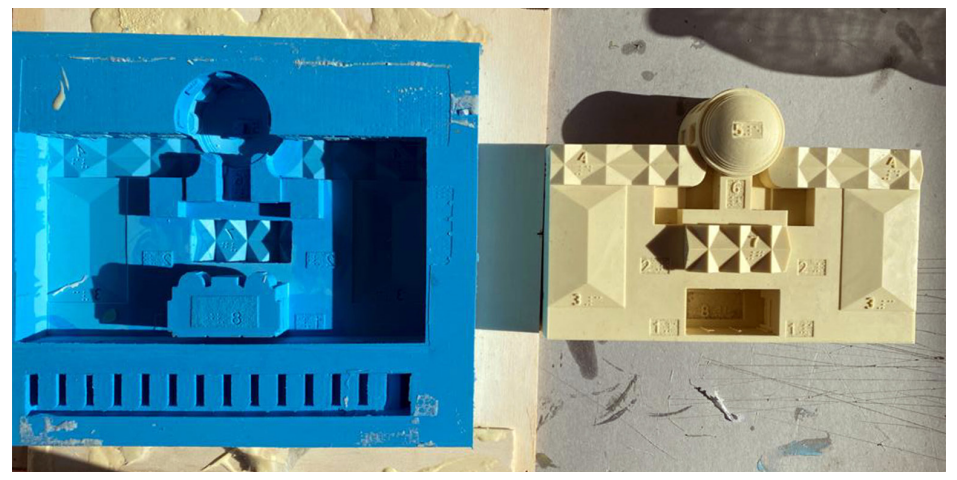

Creating a three-dimensional model of the ruins is easier, because it involves a mesh 'simplification', obtained from the integrated survey, with the necessary reductions to obtain a correct understanding of the area for the visually impaired. 3D model is integrated and transformed by closing, filling or reducing those parts that may constitute a danger during haptic exploration (fig. 6).

Reconstructing the original state requires a more accurate work. Previous reconstructive hypotheses, including some visualizations elaborated by InkLink Studio, on the recommendation of Dr. Piranomonte, were compared with the data obtained from the integrated survey and with the further discoveries and evaluations obtained during the restoration work of the upper part of the Baths. This produces new convictions on the organization of spaces, especially of large gyms, for which it is possible to hypothesize new roofs, which overcome all the hypotheses previously formulated. (figs. 7-9)

Step 3 - Use of the data

Once two three-dimensional models were validated by the representatives of the Special Superintendence for Archaeological Heritage of Rome, was created a physical model, which was also generated following different phases and procedures.

The model is designed to be placed outside, located in the entrance area. Among the requisites there is resistance to bad weather, and to be made with a material that allows haptic exploration throughout the year. Producing it using a metal material is a rejected idea, precisely due to the high temperatures it would reach in the summer, making the choice fall on a resinous material, pleasant to the touch and which solves the overheating problem. To obtain the final resin model it is first necessary to produce a negative matrix into which the material is poured, a matrix in turn generated from a 3D printed physical model. The phase preceding the printing phase sees the subdivision of the models into smaller parts, so that they fall within the limits of the printing plate; to speed up times, the models are printed using three different printers, all with FDM (Fused Deposition Modeling) technology and by extrusion of PLA (polylactate acid, made with annually renewable resources such as corn starch or sugar cane) (fig. I0).

Once the printing is complete, before the silicone matrix is made (fig. I I), a further finishing step of the object is necessary to eliminate some of the signs deriving from the additive prototyping process.

Physical model is finally positioned and fixed by screws on a polycarbonate base, made according to the methodology already acquired and tested in the previous phases of the research, with subtractive prototyping, in turn placed on a horizontal lectern (fig. 12).

\section{Conclusions}

Applied procedure allows its replicability in other areas of cultural interest, allowing at the same time both an evolution of the hypotheses of reconstruction of the sites from a scientific point of view, and their greater usability to a wider audience of visitors, making the area more inclusive. 
Fig. 12. Models printed and placed on lecterns at the entrance to the Baths.

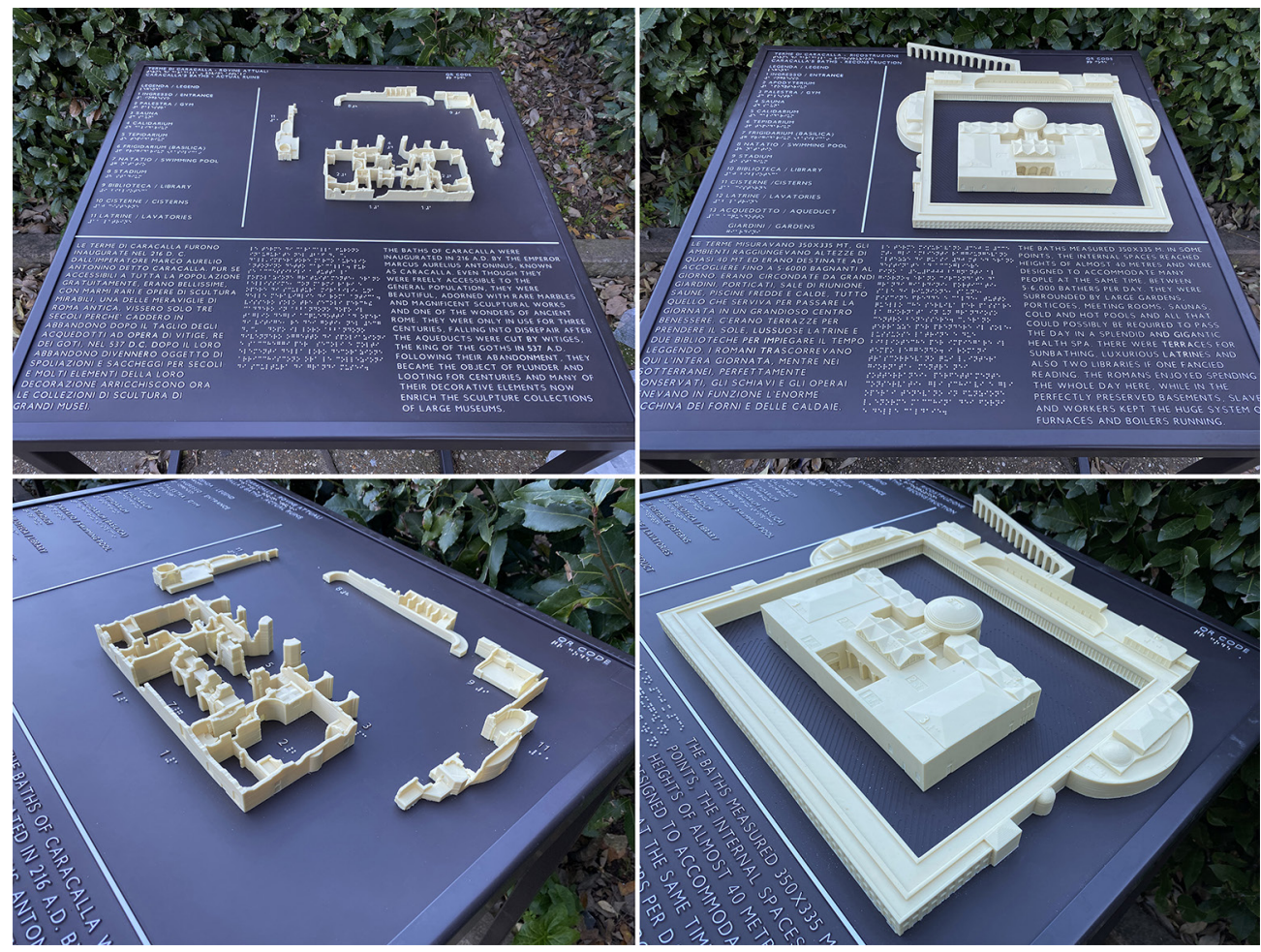

Notes

[I] Direttore archeologo coordinatore Soprintendenza Speciale per i Beni Archeologici di Roma, Direttore delle Terme di Caracalla.

[2] Soprintendenza Speciale per i Beni Archeologici di Roma, Supervisore Tecnico delle Terme di Caracalla.

\section{References}

De Luca L. (20 I I). La fotomodellazione architettonica. Rilievo, modellazione, rappresentazione di edifici a partire da fotografie. Palermo: Dario Flaccovio Editore.

Empler T. (20। 3). Universal Design: ruolo del Disegno e Rilievo. In Disegnare. Idee Immagini, n. 46, pp. 52-63.

EmplerT., Fusinetti A. (2020). Rappresentazioni a rilievo nei percorsi museali. In diségno, n. 6, pp. I69-I78.

Hall E.T. (1982). La dimensione nascosta. Milano: Bompiani.

Lemma: "Cognizione spaziale". In Treccani Dizionario di Medicina. <https://www.treccani.it/enciclopedia/cognizione-spaziale_\%28Dizionario-di-Medicina\%29/> (accessed 2021, January 24).

Lemma: “Tiflologia”. In Wikipedia. <https://it.wikipedia.org/wiki/Tiflologia> (accessed 202 I, January 24).

Millon H.S. ( 1994). I modelli architettonici nel Rinascimento. In Millon H.S., Magnago, Lampugnani V. (Eds.), Rinascimento do Brunelleschi a Michelangelo. La rappresentazione dell'Architettura, pp. 19-74. Milano: Bompiani.

Piranomonte M. (20 I2). Le terme di Caracalla/The Baths of Caracalla. Milano: Mondadori-Electa.

\section{Authors}

Tommaso Empler, Sapienza Università di Roma, tommaso.empler@uniromal.it

Alexandra Fusinetti, Sapienza Università di Roma, alexandra.fusinetti@uniroma l.it

To cite this chapter. Empler Tommaso, Fusinetti Alexandra (2021). Dal rilievo strumentale ai pannelli informativi tattili per un'utenza ampliata/ From Instrumental Surveys to Tactile Information Panels forVisually Impaired. In Arena A., Arena M., Mediati D., Raffa P. (a cura di). Connettere. Un disegno per annodare e tessere. Linguaggi Distanze Tecnologie. Atti del $42^{\circ}$ Convegno Internazionale dei Docenti delle Discipline della Rappresentazione/ Connecting. Drawing for weaving relationship. Languages Distances Technologies. Proceedings of the 42th International Conference of Representation Disciplines Teachers. Milano: FrancoAngeli, pp. 2265-2282. 